findings, raises questions but hardly settles controversies. One suspects that broken homes, for instance, do have an effect, especially where the break is caused by divorce or desertion rather than death, and especially at middle class social levels, where both breaks and delinquency are relatively less common. But it would have needed a bigger sample and further analysis to investigate such questions.

Dr McDonald's concluding discussion of the defects of the educational system, and the need to challenge teachers' assumptions about the proportion of educational failures to be expected among working class children, is eminently sensible, but not very closely related to her research results. Her experience of the unwillingness of educational authorities to permit investigation of important questions for fear of embarrassment or complaint will be appreciated by many other research workers. It is a problem that necds more open discussion. It is interesting that an author with such well developed egalitarian sentiments. and so much sympathy with the problems of the socially disadvantaged, should have succeeded in producing good evidence that, after all, lower class boys are less well behaved.

D. J. WEST

\section{CHILDREN OBSERVED}

\section{Attachment and Loss}

Vol. 1: Attachment. By John Bowlby. (The International Psycho-Analytical Library, No. 79.) P'p. $x x+428$. (Hogarth: London. Published for the Institute of Psycho-Analysis, May 1969.) $63 s$.

EXPLORING the nature of a child's tie to his mother and the consequences for his development of disrupting it in childhood has become John Bowlby's main life work. 'This volume states his views clearly and systematicaliy. It is a major contribution to the study of child development. $\mathrm{He}$ reviews relevant aspects of the new science of ethology which he uses to order the data and presents a number of major revisions of psychoanalytic theory necessitated by new observations of young children and their mothers.

Freud's metapsychology borrowed concepts from nineteenth century physies to create a model for mental activity based on a hypothetical psychic energy and its vicissitudes as it sought discharge. Bowlby's model uses concepts of "behavioral systems and their control, of information, negative feedback, and a behavioral form of homeostasis" and concepts of evolution theory which have been useful in studying the behaviour of many other animals and in terms of which their similarities to human behaviour are evident, especially the mother-infant relations of those great apes which are our closest cousins. He takes pains to emphasize the capacity of the new instinct theory to include the central clinical findings of psychomalysis: "the role of unconscious mental processes, repression as a process actively keeping them unconscious, transference as a main determinant of behavior, the origin of neurosis in infantile trauma". His theory is stated in a testable form and is closely tied to observable events.

Bv taking as units of study various social behaviour sequences which have evolved because they have survival value for the species, and which are activated and terminated by specific events and also shaped by learning, Bowlby elegantly avoids both the problems which arise from exclusive emphasis on a totally innate development which unfolds unrelated to environmental conditions and the problems of extreme behaviourism which suggests a totally plastic man. The pseudo-problems of a mind-body schism do not arise, because in his view mental events, including feelings, are aspects of appraisal processes which are constantly taking place in fredback-corrected behavioural systems.

He reviews abundant evidence which supports his statement that the infant's attachment to his mother is not largely the result of her satisfying his "oral drive" by feeding him, but arises from many component instinctive social behaviours which affect his mother and elicit contact with her, such as looking into her eyes, crying, smiling, clinging, babbling and, at older ages, distress when she leaves and efforts to follow her--to which his mother responds by picking him up, smiling at him, rocking him, looking at him, talking to him, and playing with him, to their mutual delight. "Cupboard love" is not a regression but a deviant line of development. He distinguishes progressive stages in the development of attachment behaviour from carly infancy into the preschool years. Pathological development resulting from loss of the mother will be discussed in the companion volume to follow.

Bowlby's ideas have already stimulated many fruitful observational studies of young children, and he indicates arcas in need of more rescarch. Clinical work in psychoanalysis will surely bencfit as psychoanalysts assimilate these new obscrvations and consider afresh their clinical observations relating to attachment behaviour. Mothers and those who advise them would do well to know that when mothering is an accurate response to the child's communication, he will not be spoilt by being given too much. "In an ordinary family in which a mother is caring for her child, no harm comes to hirn when she gives him as much of her presence and attention as he seems to want. Thus, in regard to mothering - as to food - a child secms to be so made that, if from the first permitted to decide, he can satisfactorily regulate his own 'intake'." In this there seems to be firm agrecment between child observation and the views of object-relations theorists such as Winnieott, Balint, Fairbairn and Guntrip, who relate pre-Oedipal psychopathology to carly frustration (privation or deprivation) of attachment neads.

There are over 300 references to the literature of child observation, ethology and psychoanalysis.

Events of the pre-verbal period of childhood, so crucial for human development, we once thought to be unreachable by psychoanalytic methods because of an emphasis on verbalization of memories. Bowlby's view makes theoretical sense of the clinical observation that when attention is paid to the transference expressions of styles of attach. ment behaviour and the image of the other person's expected responses they imply, the current residues of these early expcriences can be brought into the dialogue. As Bowlby concludes, "The truth is that the least studied phase of human development remains the phase during which a child is aequiring all that makes him most distinctively human. Here is still a continent to conquer". Leonard $J$. Friedman

\section{THOUGHTS ON SOCIOLOGY}

\section{The Logic of Social Inquiry}

By Scott Greer. Pp. xii +232 . (Aldine: Chicago, June 1969.) \$5.95.

CONTEMPORARY social scientists have to wend their way betwcen the Scylla of descriptive banality and the Charybdis of policy-oriented research. The former is, perhaps, $t$ peculiar danger for American social scientists, some of whom are rapidly destroying the subject by turning it into an unreflective empirical and quantified study; the latter is a danger to much British sociology which sceks to render the subject an adjunct merely of political administration. It is therefore important that sociologists and social psychologists pause to reflect on the nature of their activities, the possibility and potentiality of social science, and its philosophical underpinning. In this book, the American urban sociologist, Scott Greer, discusses these things with considerable felicity. His writing reveals that tolerant but confident detachment for which Texans are noted. He approaches his subject with the love and familiarity of a devoticd researcher. He offers 